\title{
Formulation and Evaluation of Ondansetron Oral Dispersible Tablet using Different
} Natural Disintegrants

\author{
Sajan Maharjan*, Shital Adhikari, Nanu KC, Sagun Dura \& Mribha Manandhar \\ Central Institute of Science and Technology (CiST College), Affiliated to Pokhara University, Sangam Chowk, New Baneshwor, \\ Kathmandu, Nepal. Email ID: maharjansajan02@gmail.com*
}

DOI: http://doi.org/10.38177/ajast.2021.5410

Copyright: () 2021 Sajan Maharjan et al. This is an open access article distributed under the terms of the Creative Commons Attribution License, which permits unrestricted use, distribution, and reproduction in any medium, provided the original author and source are credited.

\section{ABSTRACT}

Objective: The aim of this study was to develop a simple method for manufacturing oral dispersible tablets of ondansetron hydrochloride using direct compression method and to study the effect of different types and concentration of natural disintegrant (Isabgol mucilage, fenugreek mucilage and dehydrated banana powder) on the disintegrating characteristics of the tablets.

Method: Disintegrants extracted from Isabgol, fenugreek and banana powder were used in formulation of tablet using placket burman design in minitab. Then 13 different formulations (F1- F13) were prepared varying the concentration of selected natural disintegrant (Isabgol mucilage extract 6-15\%). Formulated tablets were investigated for weight variation, hardness, thickness, disintegration, drug content, friability.

Result: The result obtained from disintegration study of tablets prepared using natural disintegrant obtained from isabgol mucilage indicates that the Isabgol with concentration $11.47 \%$ shows the disintegration time of 27 seconds.

Conclusion: Orodispersible tablet of ondansetron hydrochloride was found to be effective with natural disintegrant obtained from isabgol mucilage Keywords: Ondansetron hydrochloride, Oral dispersible tablets, Natural disintegrant, Disintegration time, Isabgol.

\section{Introduction}

The tablets are designed to be taken orally which disintegrate and dissolve to release the active ingredient in a short period of time. The term "conventional tablet" is often used to describe these types of tablets. A disintegrating tablet contains usually disintegrating agents that aid in the tablet's disintegration faster than traditional tablets. As a result, the dissolving tablets dissolve faster than traditional tablets [1].

Because of its simplicity of administration, pain avoidance, self-administrability, low cost of therapy, exact dosage, self-medication, and variety, oral drug delivery is the most common route for systemic effects, resulting in high levels of patient compliance. Patients with swallowing disorders (dysphasia), as well as geriatrics patients, pediatrics patients and travelers have difficulty in swallowing tablets.

This condition is predicted to affect $50 \%$ of the population, resulting in a high rate of patient noncompliance and inefficient therapy. As a result, tablets that dissolve or disintegrate in the oral cavity have gained a lot of interest [2]. Oral dispersible tablets are made up of very porous matrices which are compressed with very low compression force. In order to increase the tablet disintegration various disintegrants are used which may be either synthetic or obtained from natural substance [3]. Several plant-based pharmaceutical excipients have been investigated for use as Pharmaceutical disintegrants by various researchers. Because of their potential to produce a wide range of materials and capabilities based on their molecular structures, polysaccharides and proteins are the focus of most studies on natural polymers for disintegrant action [4]. Natural disintegrants are used because of local accessibility, eco-friendly nature, bio-acceptable, renewable source and less side effect compared to synthetic products [5],[6]. Ondansetron is classified as a BCS (Biopharmaceutical classification system) class II drug, meaning it has a low 


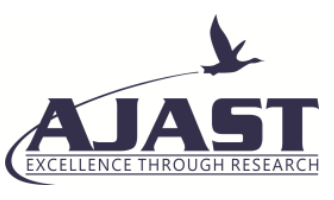

Asian Journal of Applied Science and Technology (AJAST)

Volume 5, Issue 4, Pages 82-92, Oct-Dec 2021

solubility and a high permeability. This kind of drug is ideal for oral dispersible tablet formulation. Ondansetron is a highly precise and selective antagonist of the serotonin 5-hydroxy tryptamine-3 (5-HT3) receptor. Ondansetron binds to 5-HT3 receptors selectively and competitively, inhibiting serotonin binding at vagal afferents in the gut and in emesis-related Central Nervous System areas such as the chemoreceptor trigger zone and the nucleus tractussolitarii [7].

\section{Materials and Methods}

\subsection{Materials}

Ondansetron hydrochloride was used for formulating oral dispersible tablets. The details about active ingredients and other excipients used are shown in table 1.

Table 1. List of excipients used

\begin{tabular}{|c|c|c|}
\hline Excipients & Category & Manufacturer \\
\hline Ondansetron & Active pharmaceutical agent & Gifted by Curex Pharmaceuticals \\
\hline Isabgol & Natural disintegrant & Bought from market (Greenland) \\
\hline Lactose & Diluent & Fisher Scientific \\
\hline MCC & Compression aid & Fisher Scientific \\
\hline Talc & Glidant & N.C. Industries \\
\hline Magnesium stearate & Lubricant & Fisher Scientific \\
\hline Saccharine & Sweetener & Himedia Laboratories \\
\hline
\end{tabular}

\subsection{Methods of isolation of natural disintegrant}

\section{Isolation of isabgol mucilage}

Seed of Plantago ovata was soaked in distilled water for 48 hours and then boiled for few minutes to completely release the mucilage into water. Then the water containing mucilage was squeeze through muslin cloth for filtering and separating out the marc. Subsequently, an equal volume of acetone was added to the filtrate so as to precipitate the mucilage. Then obtained mucilage was dry in hot air oven for required period of time and store in a desiccator for further use.

\section{Preparation of banana powder}

The unripe banana fruit of market was taken. Then the banana fruit was cleaned and removed the peel. Then the pulp was dried and powdered using mixer. Powdered substance was collected and stored in well closed container for further use.

\section{Fenugreek seed mucilage}

The seeds of fenugreek were powder using mortar and pestle and $100 \mathrm{~g}$ of the powder was soaked in distilled water for 48 hours and then boiled for few minutes to release the mucilage into the water. Then the fenugreek mucilage present into the water was filtered through muslin cloth to separate the marc and subsequently equal volume of 
acetone was added to the marc to precipitate the mucilage. The obtained mucilage was dried and stored in desiccator for the further use.

\subsection{Preliminary study}

For the design of all the formulations and analysis of the results, Minitab 16 software was used. Formulation design for the selection of best disintegrant among Isabgol mucilage, dehydrated banana powder, fenugreek mucilage was done using Plackett-Burman design in minitab. Formulation chart of ondansetron oral dispersible tablets for selection of best disintegrant is shown in Table 2 .

Table 2. Plackett-Burman design for selection of best disintegrant

\begin{tabular}{|c|c|c|c|c|c|c|c|c|c|c|}
\hline Z & 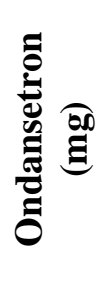 & 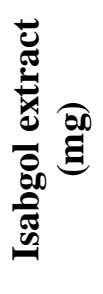 & 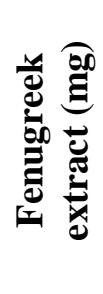 & 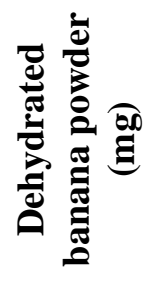 & 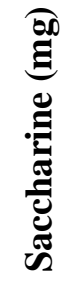 & 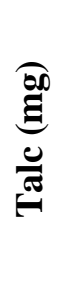 & 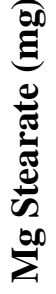 & 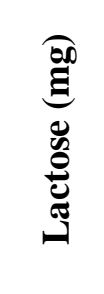 & $\underset{Z}{U}$ & 矛 \\
\hline $\mathrm{F} 1$ & 4.5 & 0 & 0 & 0 & 0.4 & 2 & 8 & 145.1 & 40 & 200 \\
\hline $\mathrm{F} 2$ & 4.5 & 12 & 0 & 0 & 0.4 & 2 & 8 & 133.1 & 40 & 200 \\
\hline F3 & 4.5 & 12 & 12 & 12 & 0.4 & 2 & 8 & 109.1 & 40 & 200 \\
\hline $\mathrm{F} 4$ & 4.5 & 12 & 0 & 12 & 0.4 & 2 & 8 & 121.1 & 40 & 200 \\
\hline F5 & 4.5 & 0 & 12 & 12 & 0.4 & 2 & 8 & 121.1 & 40 & 200 \\
\hline F6 & 4.5 & 0 & 12 & 0 & 0.4 & 2 & 8 & 133.1 & 40 & 200 \\
\hline F7 & 4.5 & 12 & 12 & 0 & 0.4 & 2 & 8 & 121.1 & 40 & 200 \\
\hline F8 & 4.5 & 12 & 0 & 12 & 0.4 & 2 & 8 & 121.1 & 40 & 200 \\
\hline F9 & 4.5 & 12 & 12 & 0 & 0.4 & 2 & 8 & 121.1 & 40 & 200 \\
\hline F10 & 4.5 & 0 & 12 & 12 & 0.4 & 2 & 8 & 121.1 & 40 & 200 \\
\hline F11 & 4.5 & 0 & 0 & 0 & 0.4 & 2 & 8 & 145.1 & 40 & 200 \\
\hline F12 & 4.5 & 0 & 0 & 12 & 0.4 & 2 & 8 & 133.1 & 40 & 200 \\
\hline F13 & 4.5 & 6 & 6 & 6 & 0.4 & 2 & 8 & 127.1 & 40 & 200 \\
\hline
\end{tabular}

\subsection{Formulation of tablet}

Ondansetron oral dispersible tablets were prepared by direct compression method. All ingredients (except API) were passed through sieve no. 60, and were weighed as per formulation design. The ingredients along with Active Pharmaceutical ingredient (API) were, mixed in an air tight polythene bag and shaken vigorously for 10 minutes. Finally, magnesium stearate was added to the mixture and shaken for 2 minutes. Then tablets were compressed using $7 \mathrm{~mm}$ biconvex round punch in 12 station rotatory compression machine. 


\subsection{Evaluation parameters of formulated tablets}

All the formulated tablets were subjected to the following quality control parameters.

\section{Weight variation}

The weight variation was carried out in order to ensure uniformity in the weight of tablets in a batch. First, the individual weight of 20 tablets was determined to find out the weight variation. The total weight of tablets from each formulation was also determined and the average weight was calculated.

\section{Thickness}

Thickness of tablets indicates the strength to withstand compression force applied during manufacturing process. Thickness of tablets was measured by vernier caliper.

\section{Hardness}

Hardness (diametric crushing strength) is a force required to break a tablet across the diameter. The hardness of a tablet is an indication of its strength the tablet should be stable to mechanical stress during handling and transportation. The degree of hardness varies with the different manufacturers and with the different types of tablets. The hardness was tested using Monsanto tester.

\section{Friability}

Ondansetron tablets were weighed collectively and place in the chamber of the friability tester. In friability tester, the tablets were exposed to rolling, resulting free fall of tablets (6 inches) within the chamber of friability tester. It will rotate at a rate of $25 \mathrm{rpm}$. After 100 rotations (4 minutes), the tablets will take out from friability tester and intact tablets will again weight collectively. Permitted friability limit is $1.0 \%$

\section{Disintegration test}

In-vitro disintegration time was determined using disintegration test apparatus as per IP specifications. Randomly six tablets were selected from each batch and test was performed with disc in distilled water using disintegration test apparatus at $37 \pm 1^{\circ} \mathrm{C}$.

\section{Dissolution test}

In-vitro dissolution of ondansetron oral dispersible tablets was performed by using type I apparatus as specified in Indian Pharmacopoeia at $50 \mathrm{rpm} .500 \mathrm{ml}$ of $0.1 \mathrm{M}$ Hydrochloric acid $(\mathrm{HCl})$ was used as dissolution medium, and the temperature of dissolution medium was maintained as $37 \pm 0.5^{\circ} \mathrm{C}$.

\section{Result and Discussion}

\subsection{Preliminary study}

As per the formulation obtained from the Placket-Burman design, disintegration time of each formulation was observed as shown in Table 3. Disintegration time of each formulation was analyzed in minitab using factorial regression to find out the best disintegrant among Isabgol mucilage, dehydrated banana powder and fenugreek mucilage. 
Table 3. Disintegration time of the formulations obtained from the

Plackett- Burman design

\begin{tabular}{|c|c|}
\hline $\begin{array}{c}\text { Formulation } \\
\text { number }\end{array}$ & $\begin{array}{c}\text { Disintegration } \\
\text { time (sec) }\end{array}$ \\
\hline F1 & 1400 \\
\hline F2 & 28 \\
\hline F3 & 90 \\
\hline F4 & 50 \\
\hline F5 & 66 \\
\hline F6 & 33 \\
\hline F7 & 33 \\
\hline F8 & 50 \\
\hline F9 & 33 \\
\hline F10 & 66 \\
\hline F11 & 1400 \\
\hline F12 & 1291 \\
\hline F13 & 60 \\
\hline
\end{tabular}

Factorial Regression of Disintegration time (DT) versus tablets prepared using Isabgol, Fenugreek and Banana Powder is shown in Table 4.

Table 4. Factorial regressions

\begin{tabular}{|c|c|c|c|c|c|}
\hline Term & Effect & $\begin{array}{c}\text { Coefficient } \\
\text { SE }\end{array}$ & Coefficient & T-Value & P-Value \\
\hline Constant & & 378 & 110 & 3.43 & 0.009 \\
\hline Isabgol & -662 & -331 & 110 & -3.00 & 0.017 \\
\hline Fenugreek & -649 & -325 & 110 & -2.94 & 0.019 \\
\hline Banana & -219 & -109 & 110 & -0.99 & 0.350 \\
\hline Ct Pt & & -318 & 398 & -0.80 & 0.447 \\
\hline
\end{tabular}

Coefficient of Isabgol was less than banana and fenugreek which shows that Isabgol has better disintegrant properties among them. So, natural disintegrant Isabgol was selected due to its better disintegration property.

\subsection{Central composite design (CCD) for the selection of best concentration of Isabgol}

Formulation was designed by minitab using $\mathrm{CCD}$ where concentration of Isabgol was selected in a range between $1-14 \%$ and talc in the range between $3-4 \%$. The formulation design is shown in Table 5.

Table 5. Formulation table using CCD

\begin{tabular}{|c|c|c|c|c|c|c|c|c|}
\hline FN & $\begin{array}{c}\text { Ondansetron } \\
(\mathbf{m g})\end{array}$ & $\begin{array}{c}\text { Isabgol } \\
(\mathbf{m g})\end{array}$ & $\begin{array}{c}\text { Talc } \\
(\mathbf{m g})\end{array}$ & $\begin{array}{c}\text { Saccharine } \\
(\mathbf{m g})\end{array}$ & $\begin{array}{c}\text { Mg } \\
\text { Stearate } \\
(\mathbf{m g})\end{array}$ & $\begin{array}{c}\text { Lactose } \\
(\mathbf{m g})\end{array}$ & $\begin{array}{c}\text { Micro } \\
\text { Crystalline } \\
\text { cellulose } \\
(\mathbf{M C C})(\mathbf{m g})\end{array}$ & $\begin{array}{c}\text { Total } \\
(\mathbf{m g})\end{array}$ \\
\hline 1 & 4.50 & 14.00 & 7.00 & 0.40 & 8.00 & 126.10 & 40.00 & 200 \\
\hline 2 & 4.50 & 24.00 & 6.00 & 0.40 & 8.00 & 117.10 & 40.00 & 200 \\
\hline 3 & 4.50 & 4.00 & 8.00 & 0.40 & 8.00 & 135.10 & 40.00 & 200 \\
\hline
\end{tabular}


Volume 5, Issue 4, Pages 82-92, Oct-Dec 2021

\begin{tabular}{|c|c|c|c|c|c|c|c|c|}
\hline 4 & 4.50 & 0.14 & 7.00 & 0.40 & 8.00 & 140.24 & 40.00 & 200 \\
\hline 5 & 4.50 & 24.00 & 8.00 & 0.40 & 8.00 & 115.10 & 40.00 & 200 \\
\hline 6 & 4.50 & 14.00 & 5.59 & 0.40 & 8.00 & 127.51 & 40.00 & 200 \\
\hline 7 & 4.50 & 14.00 & 7.00 & 0.40 & 8.00 & 126.10 & 40.00 & 200 \\
\hline 8 & 4.50 & 14.00 & 7.00 & 0.40 & 8.00 & 126.10 & 40.00 & 200 \\
\hline 9 & 4.50 & 14.00 & 7.00 & 0.40 & 8.00 & 126.10 & 40.00 & 200 \\
\hline 10 & 4.50 & 14.00 & 7.00 & 0.40 & 8.00 & 126.10 & 40.00 & 200 \\
\hline 11 & 4.50 & 14.00 & 8.41 & 0.40 & 8.00 & 124.69 & 40.00 & 200 \\
\hline 12 & 4.50 & 4.00 & 6.00 & 0.40 & 8.00 & 137.10 & 40.00 & 200 \\
\hline 13 & 4.50 & 28.14 & 7.00 & 0.40 & 8.00 & 111.96 & 40.00 & 200 \\
\hline
\end{tabular}

\subsection{Optimization of formulation}

Based on the in vitro disintegration test of all the formulations, optimization was done. The disintegration time obtained from each formulation was plotted on overlaid contour plot to find out the optimal concentration which will give the disintegration time of formulation in between 10-30 seconds. The contour plot (shown in fig.1) showed the two possible regions (higher and lower concentration of Isabgol)with the disintegration time about 20 seconds.

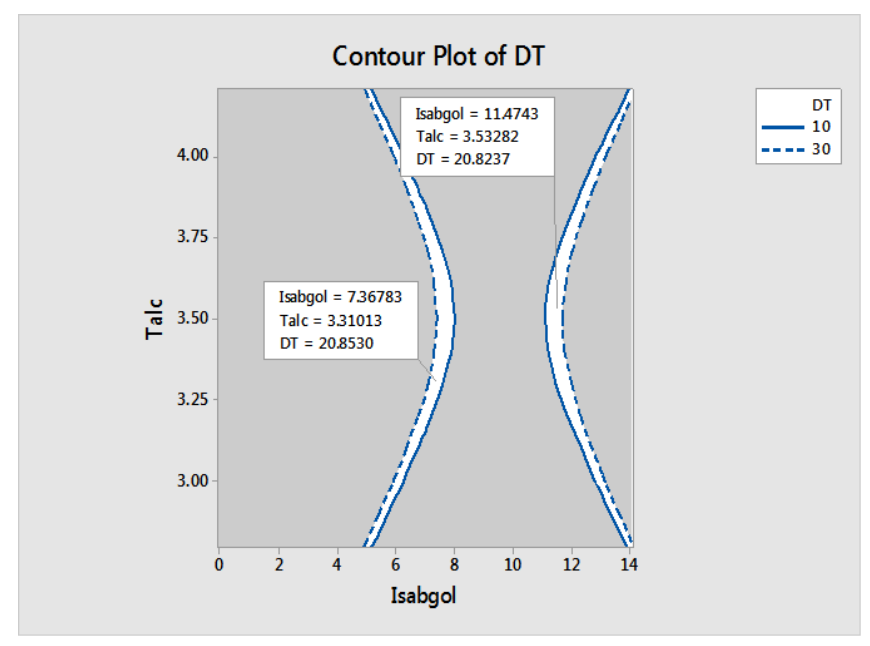

Fig.1. Overlaid contour plot of DT

\subsection{Formulation table for optimized formulation}

From the contour plot of disintegration time, two higher and lower concentration of Isabgol was selected for the formulation of optimized tablets. Higher concentration of Isabgol and lower concentration of Isabgol was indicated as $\mathrm{O} 1$ and $\mathrm{O} 2$ respectively.

Table 6. Formulation table for optimized formulation

\begin{tabular}{|c|c|c|c|c|c|c|c|c|}
\hline FN & $\begin{array}{c}\text { Ondansetron } \\
(\mathbf{m g})\end{array}$ & $\begin{array}{c}\text { Isabgol } \\
(\mathbf{m g})\end{array}$ & $\begin{array}{c}\text { Talc } \\
(\mathbf{m g})\end{array}$ & $\begin{array}{c}\text { Saccharin } \\
(\mathbf{m g})\end{array}$ & $\begin{array}{c}\text { Magnesium } \\
\text { Stearate } \\
(\mathbf{m g})\end{array}$ & $\begin{array}{c}\text { Lactose } \\
(\mathbf{m g})\end{array}$ & $\begin{array}{c}\text { MC } \\
(\mathbf{m g})\end{array}$ & $\begin{array}{c}\text { Total } \\
(\mathbf{m g})\end{array}$ \\
\hline $\mathrm{O} 1$ & 4.5 & 22.94 & 6.7 & 0.40 & 4 & 121.46 & 40 & 200 \\
\hline $\mathrm{O} 2$ & 4.5 & 14.72 & 6.6 & 0.40 & 4 & 129.78 & 40 & 200 \\
\hline
\end{tabular}




\section{NUAST}

Formulation with the higher concentration of Isabgol (O1) showed the disintegration time of 27 secs but the lower concentration (O2) showed the disintegration time of 53 secs as shown in Table 7. Hence, higher concentration of Isabgol was used as natural disintegrant for the optimized formulation.

Table 7. Disintegration time of $\mathrm{O} 1$ and $\mathrm{O} 2$

\begin{tabular}{|c|c|}
\hline FN & DT (sec) \\
\hline O1 & 27 \\
\hline O2 & 53 \\
\hline
\end{tabular}

\subsection{Evaluation of formulated tablets}

\section{Thickness}

Uniform thickness of die indicates that the die fills up was uniform. The thickness depends upon the size of the punch $7 \mathrm{~mm}$ and weight of the tablet. Thickness of the batch from formulations F1 to 13 and optimized was found to be 4.5 to $4.7 \mathrm{~mm}$ which was almost uniform in all batches.

\section{Appearance}

Tablets of all batches were round, off white in colour and plain surface on both sides.

\section{Hardness}

Hardness (diametric crushing strength) is a force required to break a tablet across the diameter. The hardness of a tablet is an indication of its strength the tablet should be stable to mechanical stress during handling and transportation. The degree of hardness varies with the different manufacturers and with the different types of tablets. The hardness was tested using Monsanto tester (Limit: Not less than (NLT) $3 \mathrm{~kg} / \mathrm{cm}^{2}$ ). Hardness of the optimized tablet was found to be $3.5 \mathrm{~kg} / \mathrm{cm}^{2}$.

Table 8. Physical evaluation of formulated tablets

\begin{tabular}{|c|c|c|c|c|}
\hline FN & Appearance & $\begin{array}{c}\text { Mean Diameter } \\
(\mathbf{m m})\end{array}$ & $\begin{array}{c}\text { Mean Thickness } \\
(\mathbf{m m})\end{array}$ & $\begin{array}{c}\text { Mean Hardness } \\
\left(\mathbf{k g} / \mathbf{c m}^{\mathbf{2}}\right)\end{array}$ \\
\hline F1 & off white & 9 & 4.7 & 3 \\
\hline F2 & off white & 9 & 4.6 & 3.3 \\
\hline F3 & off white & 8.8 & 4.7 & 3.5 \\
\hline F4 & off white & 9 & 4.7 & 3 \\
\hline F5 & off white & 9 & 4.5 & 3.6 \\
\hline F6 & off white & 9 & 4.5 & 3.4 \\
\hline F7 & off white & 8.7 & 4.6 & 3.5 \\
\hline F8 & off white & 8.6 & 4.7 & 3.4 \\
\hline F9 & off white & 9 & 4.7 & 4.7 \\
\hline F10 & off white & 8.9 & & \\
\hline
\end{tabular}


Volume 5, Issue 4, Pages 82-92, Oct-Dec 2021

\begin{tabular}{|c|c|c|c|c|}
\hline F11 & off white & 9 & 4.6 & 3 \\
\hline F12 & off white & 8.9 & 4.5 & 3.3 \\
\hline F13 & off white & 9 & 4.5 & 3.4 \\
\hline Optimized & off white & 9 & 4.6 & 3.5 \\
\hline
\end{tabular}

\section{Weight variation}

All the tablets were found to satisfy the Indian Pharmacopoeia (IP) requirements for weight uniformity. The weight variation was found in the range $\pm 7.5 \%$ of average weight.

Table 9. Weight variation range of each formulations

\begin{tabular}{|c|c|c|c|c|c|c|c|}
\hline & F1 & F2 & F3 & F4 & F5 & F6 & F7 \\
\hline $\begin{array}{c}\text { Average weight } \\
(\mathrm{mg})\end{array}$ & 201.25 & 203.6 & 198.4 & 200.8 & 200.45 & 201.3 & 199.5 \\
\hline UpperLimit (mg) & 201.63 & 218.87 & 213.28 & 215.86 & 215.48 & 216.39 & 214.46 \\
\hline LowerLimit (mg) & 186.15 & 188.42 & 183.52 & 185.63 & 185.41 & 186.20 & 184.53 \\
\hline
\end{tabular}

Table continues

\begin{tabular}{|c|c|c|c|c|c|c|c|}
\hline & F8 & F9 & F10 & F11 & F12 & F13 & Optimized \\
\hline $\begin{array}{c}\text { Average weight } \\
(\mathrm{mg})\end{array}$ & 197.1 & 202.35 & 197.35 & 199.3 & 198.55 & 200.95 & 202 \\
\hline $\begin{array}{c}\text { Average weight } \\
(\mathrm{mg})\end{array}$ & 211.88 & 217.88 & 212.15 & 214.24 & 213.44 & 216.02 & 217.15 \\
\hline $\begin{array}{c}\text { Average weight } \\
(\mathrm{mg})\end{array}$ & 182.31 & 187.17 & 182.54 & 184.35 & 183.65 & 185.87 & 186.85 \\
\hline
\end{tabular}

\section{Friability}

Friability of all the formulations was found below $1.0 \%$

\section{Disintegration time}

The disintegration time of oral dispersible tablets prepared by direct compression method were found in the range of 23-1260seconds as shown in Table 10.

Table 10. Disintegration time of each formulation

\begin{tabular}{|c|c|}
\hline FN & Disintegration Time (Secs) \\
\hline F1 & 51 \\
\hline F2 & 29 \\
\hline F3 & 71 \\
\hline F4 & 1260 \\
\hline
\end{tabular}




\begin{tabular}{|c|c|}
\hline F5 & 27 \\
\hline F6 & 45 \\
\hline F7 & 44 \\
\hline F8 & 48 \\
\hline F9 & 49 \\
\hline F10 & 44 \\
\hline F11 & 44 \\
\hline F12 & 69 \\
\hline F13 & 23 \\
\hline Optimized & 27 \\
\hline
\end{tabular}

F13 with the concentration of Isabgol mucilage 14.07\% showed fastest disintegration time of 23 secs and the optimized formulation with Isabgol mucilage concentration $11.47 \%$ showed the disintegration time 27 seconds.

\section{Dissolution test}

Dissolution testing is required for all solid oral dosage forms in order to confirm desired therapeutic effect. The best available tool today which can at least quantitatively assure about the biologic availability of a drug from its formulation is its in-vitro dissolution test.

Table 11. Drug release $\%$ on dissolution medium

\begin{tabular}{|c|c|}
\hline FN & Dissolution (\%) \\
\hline F1 & 99.53 \\
\hline F2 & 98.41 \\
\hline F3 & 101.32 \\
\hline F4 & 102.21 \\
\hline F5 & 99.65 \\
\hline F6 & 98.32 \\
\hline F7 & 97.21 \\
\hline F8 & 96.35 \\
\hline F9 & 98.65 \\
\hline F10 & 97.32 \\
\hline F11 & 98.11 \\
\hline F12 & 99.37 \\
\hline F13 & 101.39 \\
\hline Optimized & 99.31 \\
\hline
\end{tabular}

Dissolution of different formulation including optimized formulation as shown in Table 11 shows the dissolution of formulations within the range of 96.35-102.21\%. Limit of dissolution according to IP is more than $80 \%$ and all of the formulations have its dissolution within its limit. 


\section{Drug content}

The formulations comply with the test if the content of each tablet is between $90 \%$ to $110 \%$. Drug content for all the formulation batches was found to be uniform and within the range of 95.21-98.61\%.

Table 12. Drug content of each formulation

\begin{tabular}{|c|c|}
\hline FN & Assay \\
\hline F1 & $96.35 \%$ \\
\hline F2 & $95.21 \%$ \\
\hline F3 & $97.41 \%$ \\
\hline F4 & $96.54 \%$ \\
\hline F5 & $98.11 \%$ \\
\hline F6 & $98.09 \%$ \\
\hline F7 & $96.38 \%$ \\
\hline F8 & $98.29 \%$ \\
\hline F9 & $95.34 \%$ \\
\hline F10 & $96.37 \%$ \\
\hline F11 & $98.61 \%$ \\
\hline F12 & $97.73 \%$ \\
\hline F13 & $97.67 \%$ \\
\hline Optimized & $98.37 \%$ \\
\hline
\end{tabular}

\section{Conclusion}

Isabgol mucilage extract was selected by comparison among fenugreek mucilage and dehydrated banana powder using placket Burman design in Minitab by using disintegration time as major analyzing factor. Thirteen different formulations (F1- F13) were prepared varying the concentration of selected natural disintegrant (Isabgol mucilage extract $6-15 \%)$. While analyzing their disintegration time, $11.47 \%$ of Isabgol mucilage have shown the disintegration time in 27 seconds. This study was focused on the disintegrants obtained from three natural sources only with the selection of best one. Effect of each disintegrant was not studied which can be done on further works.

\section{Declarations}

\section{Source of Funding}

This research did not receive any grant from funding agencies in the public, commercial, or not-for-profit sectors.

\section{Competing Interests Statement}

The authors declare no competing financial, professional and personal interests.

\section{Consent for publication}

Authors declare that they consented for the publication of this research work.

\section{Ethical Approval}

Ethical approval was based on institutional guidelines. 


\section{References}

[1] Aulton's (2007), The design and manufacture of medicines, $3^{\text {rd }}$ Ed., 445.

[2] Bera, A. and A. Mukherjee (2013), A detailed study of mouth dissolving drug delivery system, Acta Chim Pharm Indica, 3(1): 65-93.

[3] Velmurugan, S. and S. Vinushitha (2010), Oral disintegrating tablets: An overview, International Journal of Chemical and Pharmaceutical Sciences, 1(2): 1-12.

[4] Pahwa, R. and N. Gupta (2011), Superdisintegrants in the development of orally disintegrating tablets: a review, International Journal of Pharmaceutical Sciences and Research, 2(11): 2767.

[5] Chauhan, K., et al (2013), Formulation and evaluation of Fast Dissolving Tablets of Telmisartan, International Journal of Pharmaceutical Sciences and Research, 4(4): 1514.

[6] Alam, M.T., N. Parvez, and P.K. Sharma (2014), FDA-Approved natural polymers for fast dissolving tablets, Journal of Pharmaceutics.

[7] Gan, T.J., (2005), Selective serotonin 5-HT3 receptor antagonists for postoperative nausea and vomiting, CNS drugs, 19(3): 225-238. 